\title{
RESEARCH ON BUYERS' ATTITUDES TOWARDS THE USE OF SOLAR PANELS IN HOUSEHOLDS IN THE REPUBLIC OF SERBIA
}

\author{
Dragana Nikolić Ristić* \\ Faculty of Economics in Subotica, University of Novi Sad, \\ Republic of Serbia \\ Nenad Đokić \\ Faculty of Economics in Subotica, University of Novi Sad, \\ Republic of Serbia
}

\begin{abstract}
In modern living conditions, the concept of sustainable development is one of the current research topics. In this context, the focus on greater use of renewable energy sources is supported both in the member states of the European Union and in the Republic of Serbia. The research problem of this paper refers to the attitudes of customers towards the use of renewable energy sources. The subject of the research is about the attitudes of customers towards the use of solar panels and panels in households. The first part of the paper sets out the theoretical basis of the research through a review of previous empirical studies that dealt with the same research problem, while the other sections are dedicated to explaining the research methodology, presenting and discussing the results of research on consumer attitudes towards the use of solar panels in households. The significance of this empirical study lies in the fact that it explores customer attitudes with regard to their sociodemographic characteristics.
\end{abstract}

Keywords: sustainable development, renewable energy sources, solar panels, households, buyers' attitudes, sociodemographic characteristics of buyers

JEL classification: $M 31, Q 21$

*gaganikolic@gmail.com 
74 | RESEARCH ON BUYERS' ATTITUDES TOWARDS THE USE OF SOLAR PANELS IN HOUSEHOLDS IN THE REPUBLIC OF SERBIA

\section{ISTRAŽIVANJE STAVOVA KUPACA PREMA KORIŠĆENJU SOLARNIH PANELA U DOMAĆINSTVIMA U REPUBLICI SRBIJI}

Sažetak: U savremenim uslovima života koncept održivog razvoja je jedna od aktuelnih istraživačkih tema. U tom kontekstu, fokusiranost ka većoj upotrebi obnovljivih izvora energije je podržana kako u državama članicama Evropske unije, tako i u Republici Srbiji. Problem istraživanja ovog rada se odnosi na stavove kupaca prema upotrebi obnovljivih izvora energije. Predmet istraživanja govori o stavovima kupaca prema upotrebi solarnih ploča $i$ panela u domaćinstvima. U prvom delu rada su postavljene teorijske osnove istraživanja putem pregleda prethodnih empirijskih studija koje su se bavile istim problemom istraživanja, dok su ostali delovi rada posvećeni objašnjenju istraživačke metodologije, prezentovanju i tumačenju rezultata istraživanja stavova kupaca prema upotrebi solarnih panela u domaćinstvima. Značaj ove empirijske studije se ogleda u činjenici da se ona bavi istraživanjem stavova kupaca s obzirom na njihove sociodemografske karakteristike.

Ključne reči: održivi razvoj, obnovljivi izvori energije, solarni paneli, domaćinstva, stavovi kupaca, sociodemografske karakteristike kupaca

\section{INTRODUCTION}

Customer attitudes are a topic that occupies a significant place in the theory and practice of marketing. Researching customer attitudes can provide useful information related to the needs and desires of the target customer segment, as well as their future intentions, which can be the basis for formulating adequate marketing strategies. In uncertain business conditions, permeated with business and market risk, determining the attitudes and preferences of customers is a very important factor for marketing management, from marketing strategies to decisions to optimize marketing programs (Janković-Milić \& Lepojević, 2010).

According to Živković (2014), attitudes determine the way in which a certain person perceives, feels and reacts in relation to a certain product, service, object, person or idea. They are formed under the influence of events from the past, present and planned future, as well as on the basis of their own and/or other people's experience, and they are characterized by durability and resistance to change. There is a difference between attitudes and behavior, since attitudes have the ability to direct the customer towards a particular behavior or distract it away from it. Consequently, a change in customer attitudes causes changes in customer lifestyle (Živković, 2014). 
Attitudes with a motivational character encourage customers to a certain type of behavior, and can announce a certain model of customer behavior of a particular market segment in the process of purchasing products or services (Jevtić, Alavuk \& Petrevska, 2015).

The tendency of consumers to accept the lifestyle that reflects their awareness of the importance of the environment and its preservation has become more pronounced in recent decades (Stanković, Đukić \& Stanković, 2020).

The negative effects of globalization have indicated an increasingly complex relationship between man and the environment, where the application of the concept of sustainable development appears to be a solution (Berber, 2009). The concept of sustainable development implies economic development that meets the needs of present generations, without compromising the ability to meet the needs of future generations. Berber (2009) states that renewable sources are practically inexhaustible and that there are some types of natural resources that have the ability to reproduce faster through natural processes in relation to the level consumed in the production process. In accordance with the application of the concept of sustainable development, it is necessary to change the attitudes of customers aimed at greater use of renewable energy sources.

Pokrajac (2009) states that sustainable development as a new philosophy of development implies the existence of synergy between the use of resources, investment flows, direction of technological development and institutional changes with the aim of increasing current and future potentials of human needs and desires.

Stefanovic and Azemovic (2012) conclude that the concept of sustainable development does not represent a strictly formulated definition, but a constant process of changing the relationship between social, economic and natural systems.

In the context of sustainable development and in addition to the need to research the profile of consumers of organic food in domestic conditions, the authors Grubor, Djokic and Milićevic (2018) state that there are few studies with consistent findings about the profile of such customers' unique conclusions about the profile of such consumers have not yet been reached.

According to the research conducted by Camara, Xu and Binyet (2018), the consumer is responsible for making the right decisions that encourage sustainable development, and households are one of the most important factors influencing sustainable development management. 

HOUSEHOLDS IN THE REPUBLIC OF SERBIA

The focus on renewable energy sources both in the member states of the European Union and in the Republic of Serbia, puts the concept of sustainable development in the center of attention. The subject of this study relates to the attitudes of customers towards the use of solar panels and panels in households, taking into account their socio-demographic characteristics. The structure of the paper includes the theoretical foundations of research through a review of scientific papers dealing with the research of customer attitudes in relation to energy efficient behavior and their sociodemographic characteristics. The second part of the paper includes an explanation of the research methodology, presentation of the results obtained by empirical research and discussion of the research findings on the attitudes of customers towards the use of solar panels and panels in households in the Republic of Serbia. In accordance with the importance of the concept of sustainable development and the importance of using renewable energy sources, the expectations of the authors in terms of research results are that respondents will have a positive attitude towards the use of solar panels and panels.

\section{REVIEW OF PREVIOUS LITERATURE}

\subsection{INFLUENCE OF CUSTOMER ATTITUDES ON ENERGY EFFICIENT BEHAVIOR}

Consumer attitudes are formed throughout life, with constant changes that occur under their own influence or other people's experience, family, friends or the media and determine their behavior. In the context of sustainable development, changes in consumer attitudes towards energy-saving behavior are important (Nikolić-Ristić \& Đokić, 2020).

Customer attitudes are an important variable that influences their energy-saving behavior. Sun, Liu and Zhao (2019) state that customers with a positive attitude towards the environment will be more willing to opt for "green consumption" in their daily lives and will have a higher level of green consumption, which is explained by the Theory of Self-Efficiency (Bandura, 1997). This theory focuses the researcher's attention on defining unforeseen obstacles that can affect behavior, i.e., the intention to buy and the Theory of Planned Behavior (Eisen, 1991) according to which consumer attitudes influence their intentions and if, unforeseen circumstances do not occur, they result in a purchase.

Attitudes refer to the extent to which a person has a favorable or unfavorable assessment of a particular behavior and depends on an assessment of financial costs, effort or time. Research conducted by Abrahams and Steg (2009) explains the variation in direct energy consumption (the more positive the attitudes about 
energy conservation, the lower the direct energy consumption), and the variants in direct and indirect energy savings.

Sardianou's (2007) study highlights the impact of attitudes towards the environment as a significant variable that affects energy-saving actions, and states that well-informed customers and customers with environmental awareness can be identified as "energy savers".

Attitude is identified as an important determinant of behavior, because it represents a positive or negative assessment of an individual in terms of his behavior, so people who have a positive attitude towards reducing energy use and stronger responsibility for environmental protection show more direct and indirect energy-saving behavior (Yang, Zhang \& Zhao, 2016).

The research conducted by Li, Li, Jin \& Wang (2019) starts from an extended traditional theory of planned behavior and in addition to analyzing the influence of major factors (attitudes, subjective norms and perceived behavioral control), focuses on the impact of care and knowledge of the environment on the intention to purchase energy-efficient devices of urban residents of the underdeveloped province of Shanxi in the energy-rich region of central China. In addition, 305 valid questionnaires were collected by residents of Shanxi Province using a survey method conducted from June 2018 to October 2018. Based on this, it was concluded that care for the environment, knowledge, attitudes and perceived behavior control have a significant impact on the readiness of residents to purchase energy efficient appliances. When looking at the degree of impact, attitudes have the greatest impact on the intention to purchase energy-efficient appliances (Li et al., 2019).

The results of research done by Ebrahimigharehbaghi, Qian, Meijer and Visscher (2019) show the importance of variables (barriers and initiators) that affect energy efficient consumer behavior and state that the age variable has proven to be significant, so homeowners over 35 are about 2.5 times more likely to make a positive decision on energy efficient home renovation compared to homeowners (17-35 years).

Faiers, and Neame (2006) analyzed and identified household attitudes about the characteristics of solar systems and the existence of barriers to their acceptance, based on household data in central England. The authors divided the respondents who participated in the research into two groups: "early users" 100 respondents who use solar systems and "early majority" - 1000 respondents who use other energy efficiency measures, but are not innovative enough to use solar systems. The results of empirical research show that solar systems met the expectations of "early users" which resulted in the adoption of solar system 
technology, except in terms of return investment time, where their expectations were not met. Also, the results showed that the attitudes of customers who belong to the "early majority" are positive in terms of some characteristics of solar systems, but still not positive enough to adopt and apply innovative technology of solar systems.

The results of a survey in which more than 1,000 women in Serbia took part within the WISE SEE project (Women in Sustainable Energy in South-East Europe), (2018), show that women in Serbia have a positive attitude in the context of state measures to promote sustainable energy development. The overall results show that renewable energy evokes as their first association solar panels $(83 \%)$, followed by wind energy $(76 \%)$, and finally biomass (pellet, briquette, etc.) (48\%).

\subsection{CUSTOMER ATTITUDES TOWARDS ENERGY EFFICIENCY IN THE CONTEXT OF THEIR SOCIO-DEMOGRAPHIC CHARACTERISTICS}

In analyzing gender as a socio-demographic variable, authors Yang, Zhang \& Zhao (2016) state that women have a greater propensity for indirect energysaving behavior than men. However, this difference between men and women is not significant for direct behavior when using energy. The results of the study confirm that households in which women make decisions about energy-saving behaviors show more direct energy-saving behaviors than those where men make decisions. Faiers and Neame (2006) in their research conclude that women are less likely to have the attitude that the use of solar systems negatively affects the exterior of the houses on which solar panels and panels are installed.

Also, Faiers and Neame (2006) showed that respondents older than 50 years are more likely to think that the payback period from investing in solar systems is longer, compared to younger respondents. Martinsson, Lundqvist \&Sundström (2011) confirm that with aging, there is a greater tendency to save energy, which is more pronounced in households living in separate houses, as opposed to households in flats, emphasizing that in the analysis of age variables, savings in hot water consumption is the most significant variable.

Saradianou (2007) in his research conducted in Greece confirms that the marital status of the respondents has no influence on energy saving decisions. Martinsson, Lundqvist \& Sundström (2011) believe that marital status and urbanization, sometimes show a significant impact on energy savings, but not consistently, or show a lower level of statistical significance. 
Martinsson, Lundqvist \& Sundström (2011) conclude that the relationship between environmental attitudes and energy savings is quite complex and emphasize the importance of the interaction between attitudes and socioeconomic factors. The authors state that attitudes towards the environment play a much larger role for high-income households than for low-income households.

Describing the consumers profile, Grubor and Djokic(2016) state that when buying yogurt, for women, older respondents, as well as for mostly employed and married, it is important that yogurt is produced from organic milk, because they believe that nutrition is important for health.

\section{RESEARCH METHODOLOGY}

\subsection{STRUCTURE OF THE RESEARCH SAMPLE}

The field research was conducted during 2019 on the territory of the Republic of Serbia, in the Pčinja district. Testing of the respondents was carried out using the method of personal examination. The sample included 167 respondents from the territory of the Republic of Serbia. The precondition for someone to be a respondent was that there were (or would be in the coming period) technical bases in the household to make a reorientation to the use of solar panels and panels, i.e., that it is a decision maker in this regard.

Demographic characteristics of the respondents are shown in Table 1.

Observing the structure of the sample of respondents based on marital status, we can conclude that a significant majority of respondents are married, as well as that the majority of respondents are employed. Also, in relation to the gender structure. The number of male participants was larger than female participants.

The average age of the respondents is 44.2 years (standard deviation 13.3), the average number of household members is 3.8 (standard deviation 1.5), and the average self-assessed household income is 3.5 (standard deviation 1.1). 
80 | RESEARCH ON BUYERS' ATTITUDES TOWARDS THE USE OF SOLAR PANELS IN HOUSEHOLDS IN THE REPUBLIC OF SERBIA

Table 1

Demographic characteristics of respondents

\begin{tabular}{|l|c|c|}
\hline & $\begin{array}{c}\text { Number of } \\
\text { respondents }\end{array}$ & $\begin{array}{c}\text { Percentage share } \\
(\mathbf{\%})\end{array}$ \\
\hline Gender & 94 & $56,3 \%$ \\
\hline Male & 73 & $43,7 \%$ \\
\hline Female & \multicolumn{2}{|l}{} \\
\hline Marital status \\
\hline Married & 128 & $76,6 \%$ \\
\hline Single & 39 & $23,4 \%$ \\
\hline Work status & \multicolumn{2}{|l}{} \\
\hline Employed & 120 & $71,9 \%$ \\
\hline Unemployed & 16 & $9,6 \%$ \\
\hline Pensioners & 23 & $13,8 \%$ \\
\hline Students & 8 & $4,8 \%$ \\
\hline
\end{tabular}

Note. Author's calculations.

\subsection{STRUCTURE OF THE SURVEY QUESTIONNAIRE}

The questionnaire was designed in two parts. The first part of the questionnaire referred to the socio-demographic characteristics of the respondents. In doing so, gender, age, marital status (married, single), number of household members, employment status (employed, unemployed, pensioners, students), self-assessed household income (from 1 to 5 - 1 the lowest, 5 the highest) were examined.

The second part of the questionnaire referred to the research of attitudes towards the use of solar panels and panels in the household. Attitudes were measured using a total of six statements. Each started with "Using solar panels and panels", and continued with one of the following descriptions: pleasant, likable, positive, desirable, wise, good. At the same time, the respondents expressed their attitudes using a five-point Likert scale (from "I do not agree at all" to "I completely agree"). Attitude questions were adapted from the research conducted by Eisen, Joyce, Sheikh \& Gilbert Cote (2011). The aforementioned authors used a questionnaire containing 6 statements to assess each of the four main determinants of Planned Behavior Theory (attitudes, subjective norms, perceived behavioral controls, and intentions) and applied it to a sample of 79 
graduate students. The energy conservation that students rated refers to energysaving behavior in the context of turning off lights and computers when not in use, limiting hot shower time, using a bicycle, or walking instead of taking a car. However, the results of their research challenged the assumption that good information is a prerequisite for achieving the desired results and showed that environmental knowledge had no impact on energy conservation.

\subsection{DATA PROCESSING METHODS}

Respondents' attitudes towards the use of solar panels and panels in the household were expressed by the average grade of the answers to the 6 described questions. The independent samples t-test was used to compare respondents of different gender and marital status. One-factor analysis of variance was applied to compare different segments based on work status. Pearson's correlation was used to determine the relationship between the age of the respondents, the number of household members and the self-assessed income of the household with the attitudes of the respondents towards the use of solar panels and panels in the household.

\section{DISCUSSION OF RESEARCH RESULTS}

The average assessment of respondents' attitudes towards the use of solar panels and panels in the household is shown in Table 2.

Table 2

Attitudes of respondents towards the use of solar panels and panels

\begin{tabular}{|c|c|c|c|}
\hline & N & Mean & $\begin{array}{c}\text { Standard } \\
\text { Deviation }\end{array}$ \\
\hline $\begin{array}{l}\text { Attitudes of respondents towards } \\
\text { the use of solar panels and panels }\end{array}$ & 167 & 4,33 & 0,82 \\
\hline
\end{tabular}

Note. Author's calculations.

Out of the total number of respondents, only $12 \%$ give an average grade of attitudes lower than 3.5, which indicates that the attitudes towards the use of solar panels and panels are extremely positive.

In general, with the exception of income, attitudes towards the use of solar panels and panels cannot be statistically significantly explained by the sociodemographic characteristics of the respondents. 
82 | RESEARCH ON BUYERS' ATTITUDES TOWARDS THE USE OF SOLAR PANELS IN HOUSEHOLDS IN THE REPUBLIC OF SERBIA

Test results $\mathrm{t}: \mathrm{t}(165)=0.337 ; \mathrm{p}=0.737>0.05$ show that there is no statistically significant difference between men $(M=4.31)$ and women $(M=4.34)$ in their attitudes towards the use of solar panels and panels. T-test results: $t(165)=$ $0.581 ; \mathrm{p}=0.563>0.05$ show that there is no statistically significant difference between respondents who are married $(\mathrm{M}=4.35)$ and respondents who are not married $(M=4.26)$ in attitudes towards the use of solar panels and panels.

Results of one-factor analysis of variance: $F(3)=0.743 ; p=0.528>0.05$ show that there is no statistically significant difference between the four groups employed $(M=4.38)$, unemployed $(M=4.32)$, pensioners $(M=4.20)$ and students $(M=4.00)$ regarding their attitudes towards the use of solar panels and panels.

The results of the Pearson correlation with respect to attitudes toward the use of solar panels and panels are shown in Table 3.

Table 3

Results of correlation of variables of age, household size and income

\begin{tabular}{|l|l|r|}
\hline \multirow{4}{*}{ Age } & Pearson Correlation & 0,034 \\
\cline { 2 - 3 } & Sig. (2-tailed) & 0,663 \\
\cline { 2 - 3 } & \multicolumn{1}{|l}{ Number of family members } & 167 \\
\hline \multirow{4}{*}{ Household income } & Pearson Correlation & $-0,025$ \\
\cline { 2 - 3 } & Sig. (2-tailed) & 0,752 \\
\cline { 2 - 3 } & $N$ & 167 \\
\hline & Pearson Correlation & 0,173 \\
\cline { 2 - 3 } & Sig. (2-tailed) & 0,026 \\
\cline { 2 - 3 } & $N$ & 166 \\
\hline
\end{tabular}

Note. Author's calculations.

The above results of Pearson's correlation in relation to attitudes towards the use of solar panels and panels show that there is no correlation between the age of respondents and household size with attitudes towards the use of solar panels and panels in households, while when it comes to income there is a weak, positive and statistically significant correlation with attitudes $(\mathrm{p}<0.05)$. 
The results obtained in the study partly coincide with the results obtained by Yang and his associates (2016), as well as with the research of Faiers and Neame (2006), in the sense that they show that women have a slightly more positive attitude towards the use of solar panels and panels compared to men, but this difference is extremely low.

With reference to marital status, the results of the survey are consistent with the results of Saradianou (2007) where $51 \%$ of respondents were married and the survey confirms that the marital status of respondents does not affect energy saving decisions, while the results differ from Martinsson, Lundqvist \& Sundström (2011) results who state that the marital status of the respondents can occasionally have a significant impact on energy savings, but at a lower level of statistical significance.

When it comes to the respondents' age variable, Faiers and Neame (2006) obtained different research results compared to the results presented here, as well as Martinsson, Lundqvist \& Sundström (2011) who confirm that within the analysis of the age variable, savings in hot water consumption is the most important determinant, noting that the coefficient for saving hot water is twice as high as the coefficient for heating.

However, for the income determinant, Martinsson, Lundqvist \& Sundström (2011) state that environmental attitudes play a significantly greater role for high-income households than low-income households, while this study concludes that there is a weak, positive and statistically significant correlation with attitudes when it comes to income.

\section{CONCLUSION}

Research on consumer attitudes towards the use of solar panels and panels in the Republic of Serbia is needed with respect to sustainable development concept, and ultimately to increase the use of renewable energy sources. The marketing implications of this paper relate to pointing out the factors that in modern living conditions have or do not have an effect on the attitudes of customers, as well as to consider these attitudes in general.

The results obtained in this research indicate that the attitudes towards the use of solar panels and panels are extremely positive. This finding suggests a possible connection between customer attitudes and customer awareness of the positive environmental effects of increased use of renewable energy sources. However, whether positive attitudes will be transformed into purchases also depends on the living standard and the possibility of financing energy efficient investments. 
84 | RESEARCH ON BUYERS' ATTITUDES TOWARDS THE USE OF SOLAR PANELS IN HOUSEHOLDS IN THE REPUBLIC OF SERBIA

In the context of sociodemographic characteristics of customers, the general conclusion of the research is that, with the exception of income, attitudes towards the use of solar panels and panels cannot be statistically significantly explained by the sociodemographic characteristics of respondents.

\section{REFERENCES}

Abrahamse, W., \& Steg, L. (2009). How do socio-demographic and psychological factors relate to households' direct and indirect energy use and savings? Journal of Economic Psychology, 30(5), 711-720.

Ajzen, I. (1991). The theory of planned behavior. Organizational Behavior And Human Decision Processes, 50(2), 179-211.

Ajzen, I., Joyce, N., Sheikh, S., \& Gilbert Cote, N. (2011). Knowledge and the Prediction of Behavior: The Role of Information Accuracy in the Theory of Planned Behavior. Basic And Applied Social Psychology, 33(2), 101117.

Bandura, A. (1997). Self-efficacy: The exerise of control. New York: Freeman.

Berber, N. (2009). Sustainable development from the aspect of ecological management and neoclassical economy. School of Business, 2, 16-22.

Camara, N., Xu, D., \& Binyet, E. (2018). Enhancing household energy consumption: How should it be done? Renewable and Sustainable Energy Reviews, 81, 669-681.

Ebrahimigharehbaghi, S., Qian, Q. K., Meijer, F. M., \& Visscher, H. J. (2019). Unravelling Dutch homeowners' behaviour towards energy efficiency renovations: What drives and hinders their decision-making? Energy Policy, 129, 546-561.

Faiers, A., \& Neame, C. (2006). Consumer attitudes towards domestic solar power systems. Energy Policy, 34(14), 1797-1806.

Grubor, A., \& Djokic, N. (2016). Organic food consumer profile in the Republic of Serbia. British Food Journal, 118(1), 164-182.

Grubor, A., Djokic, N. \& Milicevic, N. (2018). Serbian Organic Food Consumer Profile - Contradictions Of Previous Researches And Methodological Possibilities. School of Business, 1, 123-130. 
Jankovic-Milic, V., \& Lepojevic, V. (2010). Bayesian modeling in the analysis of combined effects. Marketing, 41(3), 171-178.

Jevtić, J., Alavuk, Đ., \& Petrevska, M. (2015). Ethical attitudes of customers in relation to the motive of travel agencies. Tourism Business, 15, 115-123.

Li, G., Li, W., Jin, Z., \& Wang, Z. (2019). Influence of Environmental Concern and Knowledge on Households 'Willingness to Purchase EnergyEfficient Appliances: A Case Study in Shanxi, China. Sustainability, 11(4), 1073.

Martinsson, J., Lundqvist, L. J., \& Sundström, A. (2011). Energy saving in Swedish households. The (relative) importance of environmental attitudes. Energy Policy, 39(9), 5182-5191.

Nikolic-Ristic, D., \& Djokic, N. (2020), Consumer Attitudes toward Use of Pellets for Energy Efficiency. Marketing, 51(1), 23-33.

Pokrajac, S. (2009). Sustainable Development and Ecological Economics As A Business Paradigm. School of Business, 4, 21-30.

Sardianou, E. (2007). Estimating energy conservation patterns of Greek households. Energy Policy, 35(7), 3778-3791.

Stankovic, Lj., Djukic, S., \& Stankovic, J. (2020). Research of consumer motives and attitudes towards "green products" as a basis for developing marketing strategies of companies in the Republic of Serbia, Marketing, 50/3, 5-16.

Stefanovic, V., \& Azemovic, N. (2012). Sustainable Development Of Tourism In An Example Of Vlasinska Povrs. School of Business, 1, 38-50.

Sun, Y., Liu, N., \& Zhao, M. (2019). Factors and mechanisms affecting green consumption in China: A multilevel analysis. Journal of Cleaner Production, 209(1), 481-493.

WISE SEE (2018). Women in Sustainable Energy, Climate Change and the Environment - Leadership for Change.

Yang, S., Zhang, Y., \& Zhao, D. (2016). Who exhibits more energy-saving behavior in direct and indirect ways in China? The role of psychological factors and socio-demographics. Energy Policy, 93, 196-205.

Živković, R. (2014). Customer behavior. Belgrade: SingidunumUniversity.

Delivered: 20.04.2020.

Accepted: 20.11.2020. 